\title{
METHODOLOGY FOR ASSESSING THE ROMANIAN FUNCTIONAL URBAN AREAS USING GIS AND LAU 2 TERRITORIAL INDICATORS
}

\author{
Antonio Valentin TACHE \\ National Institute for Research and Development in Constructions, Urban Planning and Sustainable Territorial \\ Development; "URBAN-INCERC", URBANPROIECT Branch, Department of Territorial Cooperation, Environment and \\ Territory Observation, Bucharest, ROMANIA \\ tonytache62@gmail.com
}

\section{Oana-Cătălina POPESCU}

National Institute for Research and Development in Constructions, Urban Planning and Sustainable Territorial Development; “URBAN-INCERC", URBANPROIECT Branch, Department of Territorial Cooperation, Environment and Territory Observation, Bucharest, ROMANIA

oana.katalina2006@gmail.com

\section{Sorin Daniel MANOLE}

"Constantin Brâncoveanu" University, Piteşti, ROMANIA

danielsorinmanole@yahoo.com

\section{Alexandru-Ionuț PETRIŞOR}

Doctoral School of Urban Planning, Ion Mincu University of Architecture and Urban Planning, Bucharest, ROMANIA alexandru.petrisor@uauim.ro

DOI: http://doi.org/10.23740/TID120182

\section{ABSTRACT}

The territorial dimension of the European convergence policy is represented by polycentricity. The main challenge in promoting a polycentric and balanced territorial development is represented by an accurate delineation of the functional urban areas. Effective development strategies require the extension of functional areas to be scientifically defined as a critical mass. According to several studies, Functional Urban / Metropolitan Areas can be determined based on the number of commuters going to the core city, in different shares of the total economically active population. The evaluation of the polycentric development of the network of settlements in Romania is hampered by the lack of reliable data on the number of commuters at the settlement level. The indicator is not statistically monitored and consequently misses from the list of indicators quantified by the National Institute of Statistics. Therefore, the present study has as main purpose to identify the Functional Urban Areas in Romania for cities with more than 30,000 inhabitants. The methodology is based on the statistical support of ArcGIS 10.3 and on analyses based on indicators such as population and number of employees (absolute values and dynamics) at the level of settlements (LAU 2). The results of the study consist of mapping the functional urban areas of the large Romanian cities, which allows an assessment of the legally constituted metropolitan areas of Romania. 


\section{INTRODUCTION}

The topic of polycentrism has gained importance in recent years and has become a normative concept in the European agenda of spatial planning (Faludi, 2006; Eskelinen \& Fritsch, 2009; Petrişor, 2017). According to the main territorial documents of the European Union, polycentric development represents a strategic tool that can promote economic competitiveness (Hague \& Kirk, 2003), social cohesion (Meijers et al., 2008) and environmental sustainability (CSD, 1999). In a polycentric system, the development of each city (as an element of the urban system) depends on its territorial capital and relevant assets providing location-based advantages regarding its competitiveness on different spatial levels (Giffinger \& Gudrun, 2010). Assessing the polycentric structure of national urban systems is a relevant task for policies, because it is necessary to understand the contribution of different regions to national prosperity and whether the investment priorities should move towards few large and capital cities or spread in a wider set of cities (Brezzi \& Veneri, 2015; Annoni \& Dijkstra, 2013). One of the main issues when performing analysis of polycentric regions and proposing regional development policies is that there are no widely used standards to identify them (Davoudi, 2003). In polycentric regions, cities are well-connected (Meijers, 2008) and interrelated through cooperation flows (Cowell, 2010). Today, more and more jobs are created in the fringe areas, e.g. along the motorways and in the proximity of airports, but people prefer to live in the city centres resulting in genuine two-way travel-to-work flows. Thus, the core (centre) of an urban region and its fringe areas (adjacent urban areas) have formed an increasingly interwoven and interactive functional region (Van der Laan, 1998).

In order to assess a country's polycentricity, it is necessary first to establish functional urban areas. The delineation of functional urban areas in most European countries is based on the same principle, i.e., the commuting conditions. However, despite this similarity in the approach towards their definition, differences in the conceptual basis suggest a distinction depending on certain specific characteristics of the country and implicitly on the size factor. The compatibility between functional and administrative regions is an important issue since it reflects the way in which different territorial levels fit together and can determine administrative tasks and responsibilities. The new spatial development perspective is a dynamic concept; cities are not seen only as supply centres, but also as engines of development (Schindegger, 2002). Sassen (2001) and Castells (1996) emphasize the relevance of flows between the nodes of the network drawn by the global economy; "flow" means the exchange of goods, capital, people, and information.

To be able to represent development and polarization factors, cities should be understood as dynamic functional areas. The lack of an optimal definition of functional urban areas can undermine even the best local strategies and ultimately lead to unsatisfactory results in terms of development. Functional urban areas are often identified with metropolitan areas.

The development of Europe's economic territory today can be characterized as a process of metropolisation of economic development potentials and innovation capacities (Krätke, 2007). Functional specialization is an important dimension of polycentricity, as it can differentiate cities and produce the necessary flows for economic and political integration. Metropolisation is one of the most dynamic processes of the contemporary world, being able to change the existing settlement patterns or create new relations between large cities (Jałowiecki, 2006). According to Privelli (2003), the extent of metropolitan functions in the contemporary world depends on the type and quality of services offered by the city, on the level of scientific and technological development, on the abilities of service providers and consumers to use the 
achievements of civilization, on the economic, technical and legal access to these functions, on the type of legal and administrative system, and on the political situation.

The new vision on spatial planning at European and global level refers to the evolution of cities as intelligent metropolis. According to Giffinger and Godrun, the term "intelligent" incurs, in particular, the implicit or explicit ambition of a city to improve its economic, social and environmental standards, and therefore its competitiveness in urban competition.

In Romania, the creation of intelligent metropolitan areas at European level requires a new strategy to maximize the integrated development of major cities. Changes that have known metropolitan areas as time and space reflect the evolution of economy and society (Boix et al., 2012). Analyses conducted lately demonstrate an economic and social development at different speeds (Tache \& Petrişor, 2017). In this regard, it is imperative to carry out a diagnostic analysis to redefine the real functional urban areas of the Romanian municipalities functioning as county seats, highlighting their socio-economic typology, and their functional / intelligent functional specializations.

This study aims to present a methodology developed to approximate the Functional Urban Areas around major Romanian cities based on the statistical support of ArcGIS 10.3 and on the dynamics of specific indicators (population and number of employees) at the LAU 2 administrative level.

\section{METHODOLOGY}

The most commonly used and applied methods in the evaluation of polycentrism are the techniques based on the Geographic Information Systems - GIS (Nordregio et al., 2005; Hoyler et al., 2008; Petrişor, 2016) and spatial econometric techniques, using in particular the estimation of nonlinear functions (McDonald \& Prather, 1991; Meijers \& Sandberg, 2008), the method of the smallest ordinary squares (Trullén \& Boix, 2001) or weighted regressions (McMillen \& McDonald, 1998; McMillen \& Smith, 2003). Descriptive statistics can also be applied, which use indicators such as the Gini coefficients, localization and specialization coefficients (Gordon \& Richardson, 1996; Trullén \& Boix, 2003; Meijers, 2008) and the Moran index (Baumont et al., 2004; Guillain et al., 2004). Quantitative and cartographic approaches can be quickly performed. They can rapidly communicate the results to policy makers and, using iterations, the impact of different alternative planning scenarios can be tested (Marull et al., 2007).

A polycentric network relies on large urban areas with an important growth potential in the settlement network and a transport infrastructure able to efficiently interconnect the areas with a competitive potential. At a national level, polycentric development is needed in order to identify priorities and development goals. It is also necessary to develop an effective polycentric network, directly correlated with functional and strategic levels at a regional, county and local scale (Tache \& Tache, 2016).

Urban areas seen as polycentric development nodes have been the subject of numerous studies at European and national level. Some of them delineate Functional Urban Areas (Functional Metropolitan Areas) based on commuting data towards the workplace, with a 15\% threshold of the number of commuters to the core city reported to the economically active population. Unfortunately, in Romania, data on the number of commuters at LAU 2 administrative level is not provided by the Romanian National Institute of Statistics; such data 
are collected by municipalities and often lack evaluation techniques or scientific models. In more details, the County Divisions of Statistics receive LAU 2 data on commuters from the specialized personnel of the city or commune administrations. However, these data highlighted large gaps among counties, as underlined by the project "Administrative-territorial Reform: Towards More Efficient Local Administrations in Romania", co-funded by the European Social Fund through the Operational Program "Development of the Administrative Capacity" (code SMIS 32602). As a result, some of the collected data is not in line with reality, creating confusion in the local analyses.

The lack of data on the number of commuters in Romanian major cities entails an approximate delineation of Functional Urban Areas determined by specific indicators and assessment methods. For these reasons, this study has developed a methodology for the evaluation of the Functional Urban Areas of major Romanian cities based on the GIS techniques and on statistical indicators referring to population and employees at the lowest administrative level (LAU 2). The spatial database was uploaded with data for the period $2008-2015$ that allow the assessment of their dynamics, too. Since the primary interest focused on recent dynamics of metropolitan areas in terms of population and number of employees, the years of particular interest were: 2008 (real estate boom), 2011 (first post-crisis year, its inclusion might offer hints on the economic resilience), and 2015/2016 (last years covered by data). For the evaluation of the Romanian Functional Urban Areas, 77 cities/municipalities with a population of more than 30,000 inhabitants were considered, totalizing 9,706,632 inhabitants (in 2015). Several synthetic maps were drawn up to highlight the potential of these cities and their adjacent areas.

The methodology consists of a quantitative analysis using relevant statistical indicators and a qualitative impact criterion. In this regard, the purpose of the methodology is to identify those combinations of statistical indicators that really make sense in the logical order of criteria which were used to identify the functional urban areas. For this reason, the reference years were 2008, 2011, and 2015 for the number of employees, and, respectively, 2008, 2011, and 2016 for the population. 2008 corresponds to the peak of Romanian economic development, 2011 is the year when economy showed its first positive post-crisis trends, and 2015 and 2016 are the last years covered by statistical data.

In order to make a correct evaluation of the Functional Urban Areas in Romania, the methodology for the evaluation of the overall territorial index (Tache et al., 2017) was used in a modified form. The original methodology was based on statistical indicators used for spatial planning activity and on an innovative mathematical solution that used the Natural Breaks (Jenks) classification scheme. In this study, equal intervals were used instead of Jenks classification. The statistical indicators belong to the following domains: Population, Transport, Economy, Utilities, Natural Conditions, Social, and Culture. An overall territorial index was computed by weighting the values of all indicators used in above-mentioned areas. The weights established by the specialists working in the field of spatial planning were the following:

- Index for the POPULATION chapter - 17\%,

- Index for the TRANSPORT chapter-17\%,

- Index for the ECONOMY chapter-28\%,

- Index for the NATURAL CONDITIONS chapter - 10\%,

- Index for the UTILITIES chapter-10\%, 
- Index for the SOCIAL chapter - 10\%,

- Index for the CULTURE chapter - 8\%.

The ArcGIS 10.3 software was used for mapping the competitiveness of Romanian settlements, by overlaying all maps against the territorial index map, producing a synthetic map of potential functional urban areas, sorted using the software provided criteria.

\section{RESULTS AND DISCUSSION}

The synthetic map (Figure 1) presents the dynamic of the number of employees and of the number of inhabitants between 2011 and 2015 at LAU2 level (the level of locality) in Romania.

Figure 1 shows that the Romanian cities over 30,000 inhabitants had the following dynamic (data for the years 2008, 2011, and 2015):

- The cities that had a positive dynamic of the population in 2015 compared to 2011 are: Alba Iulia, Bacău, Bistriţa, Cluj-Napoca, Iaşi, Năvodari, Rădăuţi, Săcele, Sebeş, Sibiu, Vaslui, Voluntari. If in the case of large cities (such as Cluj-Napoca, Iaşi, Sibiu, Alba Iulia, Bacău and even Bistrița or Vaslui), growth was due to an increase of the economic potential and due to the attraction of the work force from the peripheral cities, small and average towns (such as Rădăuţi, Săcele, Sebeş, Voluntari, Năvodari) can attract, through their functional specializations, the work force of adjacent areas and neighbouring large cities. It can be noticed that major cities did not have a positive dynamic of population in this period, such as Bucharest, Timişoara, Arad, Braşov, Constanţa, Oradea, Craiova, Satu Mare, Baia Mare or Suceava, although their adjacent settlements have a positive dynamic of population and employees between 2011 and 2015. In the case of Bucharest, the capital of Romania, and in many county seats, the population dynamic was due to the development of metropolitan areas (Tache et al., 2018), which led to a migration of the population of the urban core to the hinterland areas. External migration was an important factor in the case of young people, especially for those having an education above the average.

- Most cities had an increase in the number of employees in 2015 compared to 2011 (58 out of 77 cities), except for the cities: Sighetu Marmaţiei, Dorohoi, Dej, Turda, Timişoara, Lugoj, Caransebeş, Hunedoara, Petroşani, Făgăraş, Săcele, Râmnicu Vâlcea, Curtea de Argeş, Ploieşti, Miercurea Ciuc, Oneşti, Vaslui, Bârlad, and Feteşti. It is to be noticed that Timişoara and Ploieşti have a peri-urban area with a positive economic dynamic, although the number of employees in these two municipalities in 2015 was lower than the number of employees in 2011. The increase of the number of employees in most cities during 2011-2015 was a normal consequence after its abrupt decrease during 2008-2010. However, some cities understood the need for implementing integrated development strategies aimed at increasing their attractiveness and using European funds to attract investments and improve their management; all these resulted in increasing their competitiveness faster than other cities.

- An analysis of the population in these cities between 2008 and 2015 (since the beginning of the economic crisis) shows a continuous increase in the following cities: Alba lulia, Bistrița, Cluj-Napoca, Iaşi, Năvodari, Rădăuţi, Săcele, Sebeş, Sibiu, and Voluntari. A similar analysis shows that, in the same period, only Voluntari had a constant increase of the number of employees. The dynamic during 2008-2015 is an indicator of the resilience of Romanian cities to the global 2006-2010 economic crisis. Only some large county seats, such as Cluj-Napoca, Alba Iulia, Sibiu, Bistriţa and partially laşi show positive trends. Average cities, such as Săcele, 
Sebeş, Voluntari and to a lesser extent Rădăuţi are satellites of large cities that benefited upon investments in the last 10 years, used to develop large residential assemblies.

- Considering the dynamic of the population in 2008, 2011 and 2015, the results show that there are prerequisites for the formation of metropolitan areas around the following cities: Bucharest, Constanţa, Arad, Timişoara, Sibiu, Iaşi, Cluj-Napoca, Oradea, Ploieşti, Braşov, TârguMureş, Bistriţa, Buzău, Satu Mare, Alba Iulia, Suceava, Piatra Neamţ, Bacău, Făgăraş, Sighişoara, and Odorheiu Secuiesc.

- The areas considered to be partially metropolitan in terms of population dynamic are: the periurban area Brăila-Galaţi and cities Baia Mare, Focşani, Botoşani, Râmnicu Vâlcea, Târgovişte, Craiova, Miercurea Ciuc, Deva, Sfântu Gheorghe, and Rădăuţi.

- Considering the dynamic of the number of employees in the period 2008-2011-2015, the results indicate that there are premises for the formation of the metropolitan areas around the cities of Arad and Ploieşti.

- The areas considered to be partially metropolitan in terms of the dynamic of the number of employees are the cities: Bucharest, Timișoara, Cluj-Napoca, Alba lulia, Sibiu, ConstanţaMangalia-Medgidia, Oradea, Piteşti-Mioveni, Baia Mare, Satu Mare, Bistriţa, Buzău, Târgu Mureş, Suceava, Galaţi, Lugoj, Odorheiu Secuiesc, Sighişoara, and Făgăraş.

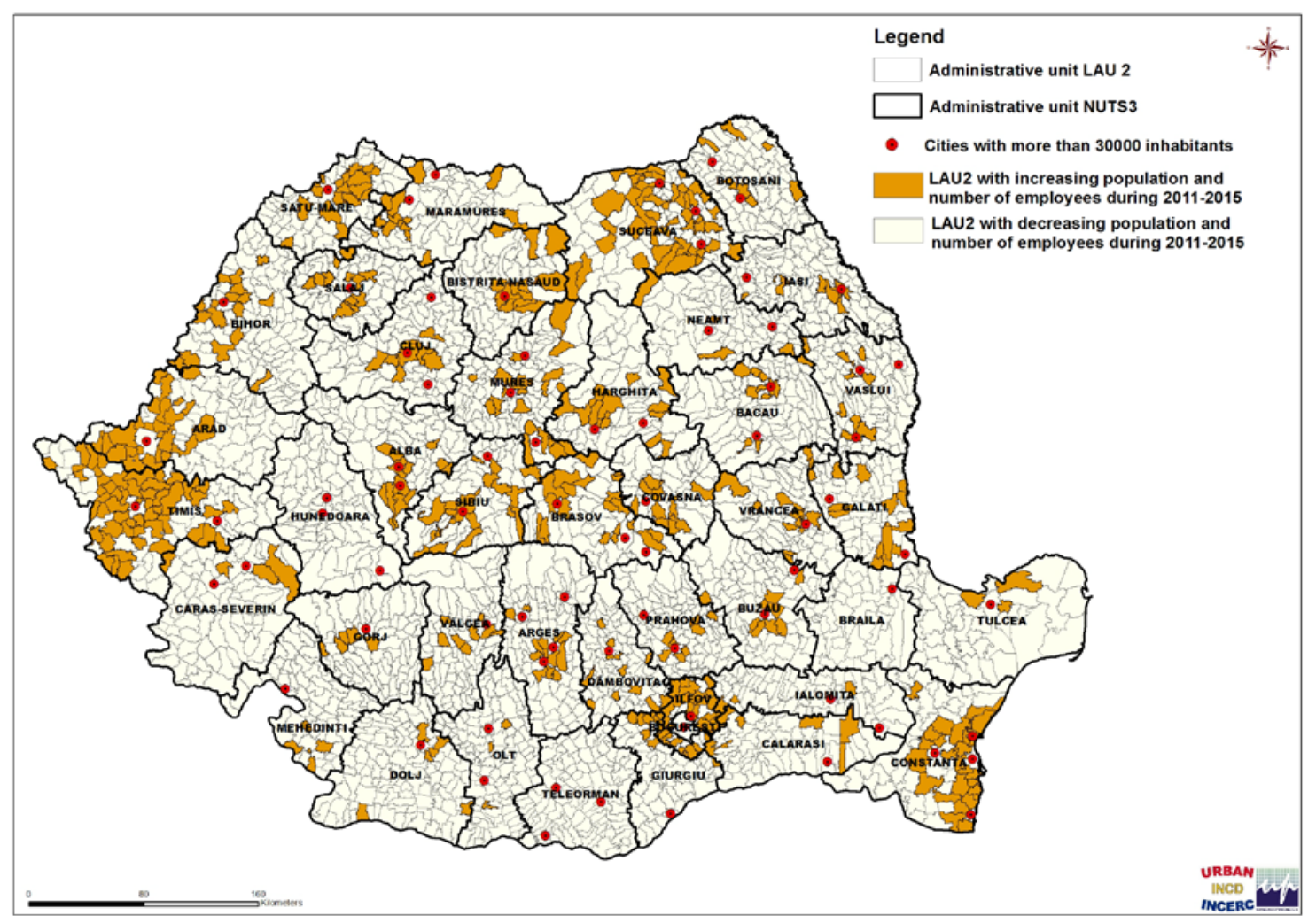

Figure 1: The dynamic of population and employees between 2011 and 2015 at settlement level (LAU 2) 
Another type of analysis for assessing the Functional Urban Areas in Romania was made using the ratio between the number of employees and that of the population in the years 2011 and 2015. Figure 2 shows the dynamic of the number of employees relative to the population in 2011, on the 10 categories of the standard classification scheme on Natural Breaks (Jencks), obtained using the ArcGIS 10.3 statistical support.

The ratio of the number of employees and the number of people at the level of settlements in 2011 shows increased values in the periurban area of Bucharest and Oradea, and partially in the area of Arad, Braşov, Sibiu, Deva, Alba lulia and Târgu Mureş municipalities. Increased values of this ratio were also found in the southern part of Gorj County, the northern part of Vâlcea County and in the southern part of Sibiu County.

On the opposite side, large areas of the country have low and very low values for this ratio, such as Iaşi, Vaslui and Botoşani Counties, the eastern part of Suceava, Neamţ and Bacău Counties, and counties like Vrancea, Galaţi, Teleorman, Olt, Dolj, Mehedinţi, Dâmboviţa, partially in Călăraşi, Ialomiţa, Brăila, Constanţa, Tulcea Counties, the southern part of Argeş, Sălaj and Satu Mare Counties, the western part of Bistriţa-Năsăud County and in several areas belonging to Caraş-Severin, Buzău, and Covasna Counties.

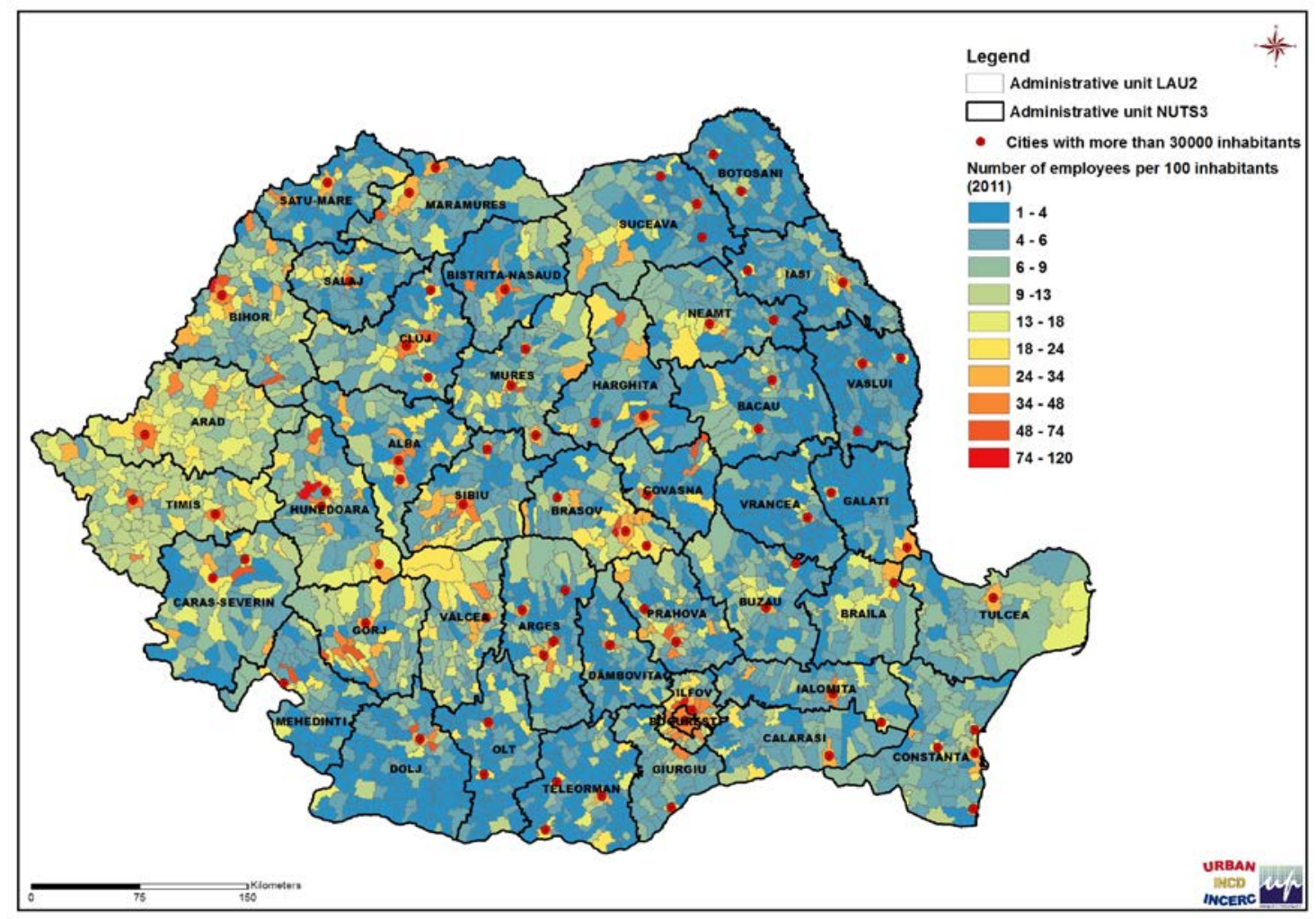

Figure 2: Ratio of employees and population in 2011 at settlement level (LAU 2) Source: Romanian National Institute of Statistics - Tempo Online Database

This analysis proves the capacity of Bucharest, the Romanian capital, and other large cities of Transylvania and Banat to generate the economic development of their peri-urban areas, but also the incapacity of the large cities of Moldova and Muntenia to regenerate after the economic crisis and irradiate development towards their peripheries. 
The map presented in Figure 3 illustrates the ratio of the number of employees and population in 2015 , on the 10 categories of the standard classification scheme on Natural Breaks (Jencks), obtained using the ArcGIS 10.3 statistical support.

According to these findings, there is a sharp increase of the ratio of the number of employees and of the population in the area of Arad and Timiș Counties, compared to 2011. Practically Timiş County has a significant increase in all settlements, and the peri-urban area around Timișoara is forming a metropolitan area with high potential for development.

The same increase of this report was found in Arad County, at the intersection between Arad and Timişoara and metropolitan areas, being created the premises for the appearance of a corridor of great potential for economic development. A similar corridor of economic development seems to be created in the corridor Sibiu-Sebeş-Alba lulia. Otherwise, the same areas as in 2011 have high values of this ratio at LAU 2 level in 2015, as well as the low and very low values.

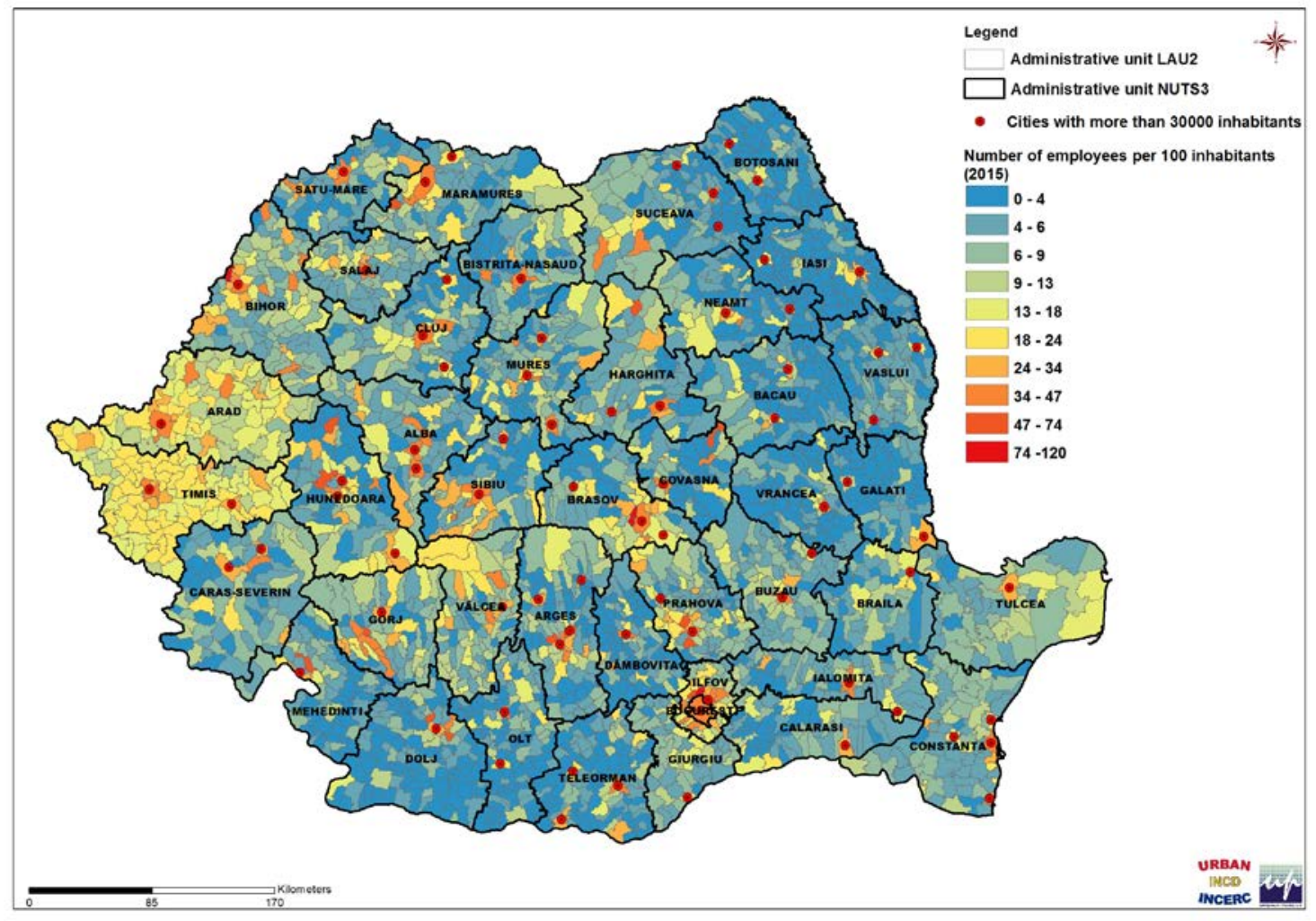

Figure 3: Ratio of employees and population in 2015 at the settlement level (LAU 2)

Source: Romanian National Institute of Statistics - Tempo Online Database

The map identifies areas and corridors with a future potential for development. It also shows the need for developing the Timişoara-Arad conurbation, with a high potential, of the economic corridors Bucureşti-Ploieşti-Braşov, Satu Mare-Baia Mare, Sibiu-Sebeş-Alba, BacăuPiatra Neamţ, and of the large cities, such as Cluj-Napoca, Oradea, Piteşti, and Constanţa which generated work places in their hinterland and important commuting flows. 
In order to have a clearer picture of the dynamic of the number of employees in relation to the population between 2011 and 2015, a map presenting the dynamic of the ratio employees/population in the period 2011-2015 was created (Figure 4).

The dynamic of the ratio employees/population at LAU 2 level in the period 2011-2015 reveals a positive trend of settlements belonging to Arad, Timiș, Alba, Sălaj, Teleorman, and Vaslui Counties, although they are less developed. A positive trend is also found for settlements belonging to Olt, Argeş, Prahova, Buzău, Vrancea, Constanţa, Satu Mare, Covasna, Galaţi, and Suceava Counties.

The analysis shows, similar to the previous findings, the capacity of many Romanian cities to generate work places in their core and peripheries. The list includes Bucharest, the Romanian capital, and large cities from the West, such as: Timişoara, Arad, Cluj-Napoca, Oradea, Braşov, Sibiu, Alba Iulia, Târgu-Mureş, Baia Mare, and Satu Mare. Several cities of Muntenia show a potential for generating work places in their peripheries: Constanţa, Piteşti, and Ploieşti. Unfortunately, the large cities in Moldova have a moderate growth trend; laşi attracted recently IT investments, because it is a large academic centre, with national importance. The increase of the number of employees in the cities of Muntenia and Moldova are due to the overall growth trend of the national economy, which is still unable to compensate the massive employee losses during 2008 and 2010.

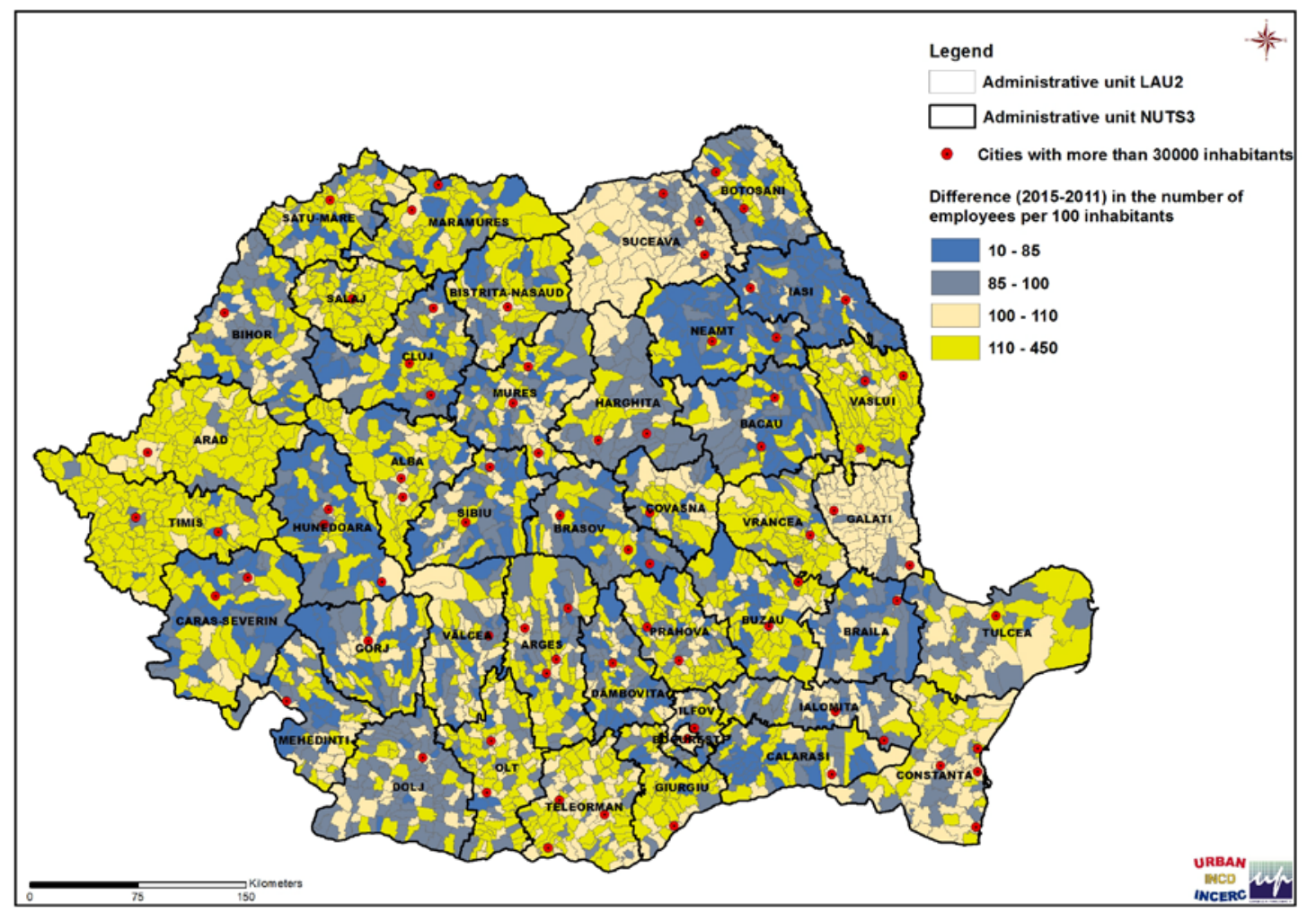

Figure 4: Dynamic of the ratio of employees and population between 2011 and 2015 at the settlement level (LAU 2) 
Negative dynamics of this ratio between 2011 and 2015 was true for the following counties: Neamţ, Iaşi, Bacău, Brăila, Braşov, Dâmboviţa, Hunedoara, and Ilfov. There was a decrease in the dynamics of this ratio even in the developed areas of Romania, such as Ilfov and Braşov Counties.

The ratio of employment and population is very high in the western area of Romania (especially in Arad and Timiş Counties) showing very high dynamics in the period 2011-2015. Although very high values of this ratio were found in Bucharest and Ilfov County, as well as in the regions surrounding big cities such as Cluj-Napoca, Sibiu, Braşov, Alba lulia, and Târgu Mureş, these areas had low dynamics between 2011 and 2015 (excepting Alba County).

Many settlements have low and very low ratio of employees and population, such as those belonging to laşi, Vaslui and Botoşani Counties, the eastern part of Suceava, Neamţ and Bacău Counties, Vrancea, Galaţi, Teleorman, Olt, Dolj, Mehedinţi and Dâmboviţa Counties, partially Călăraşi, Ialomiţa, Brăila, Constanţa and Tulcea Counties, the Southern part of Argeş, Sălaj and Satu Mare Counties, the west part of Bistriţa-Năsăud County, and areas belonging to CaraşSeverin, Buzău and Covasna Counties.

However, in the case of Teleorman, Vaslui, Vrancea, Buzău, Olt, Constanţa, Tulcea, Suceava, Sălaj, Satu Mare or Covasna Counties, the dynamics of the employees-population ratio between 2011 and 2015 was high and very high.

Unfortunately, there are large areas in Romania characterized by low/very low values of this ratio and of its dynamics in this period, such as laşi, Neamţ, Bacău, Dolj and Brăila Counties, as well as many communes belonging to Mehedinţi, lalomiţa, Călăraşi, Caraş-Severin or Hunedoara Counties.

Using the weighted indices, the map of the territorial index was drawn up at the settlement level (LAU 2). The attractiveness index grouping was performed using 10 intervals according to the Natural Breaks (Jencks) standard breakdown scheme, obtaining 10 groups, to which scores from 1 to 10 were assigned in increasing order (Figure 5). The map is an output of the methodology developed by Tache et al. (2016), presented in the previous section; the main result of this study is the territorial competitiveness index of LAU2 units in Romania. The yellow/orange areas have a higher economic potential than the national average, and the blue ones are situated below it.

All these findings made possible an evaluation for all Romanian functional urban areas corresponding to the neighbouring areas of big cities (with more than 30,000 inhabitants). The resulting map of functional urban areas is presented in Figure 6.

A first remark related to these results is that, in Romania, the actual metropolitan areas, legally established through association and based on voluntary partnership, are much more extensive than the functional urban areas resulting from the present study, with the exception of Arad and Timișoara. It can be concluded that in Romania the metropolitan areas, as established on a political basis so far, can emerge through realistic metropolitan development plans and effective metropolitan governance. Based on the results, the only Romanian functional urban areas are the Arad-Timişoara conurbation, Oradea, and Bucharest. The potential functional urban areas are situated around Braşov, Constanţa, Baia Mare, Ploieşti, and Piteşti. 
Antonio Valentin TACHE, Oana-Cătălina POPESCU, Sorin Daniel MANOLE, Alexandru-lonuț PETRIŞOR Methodology for Assessing the Romanian Functional Urban Areas

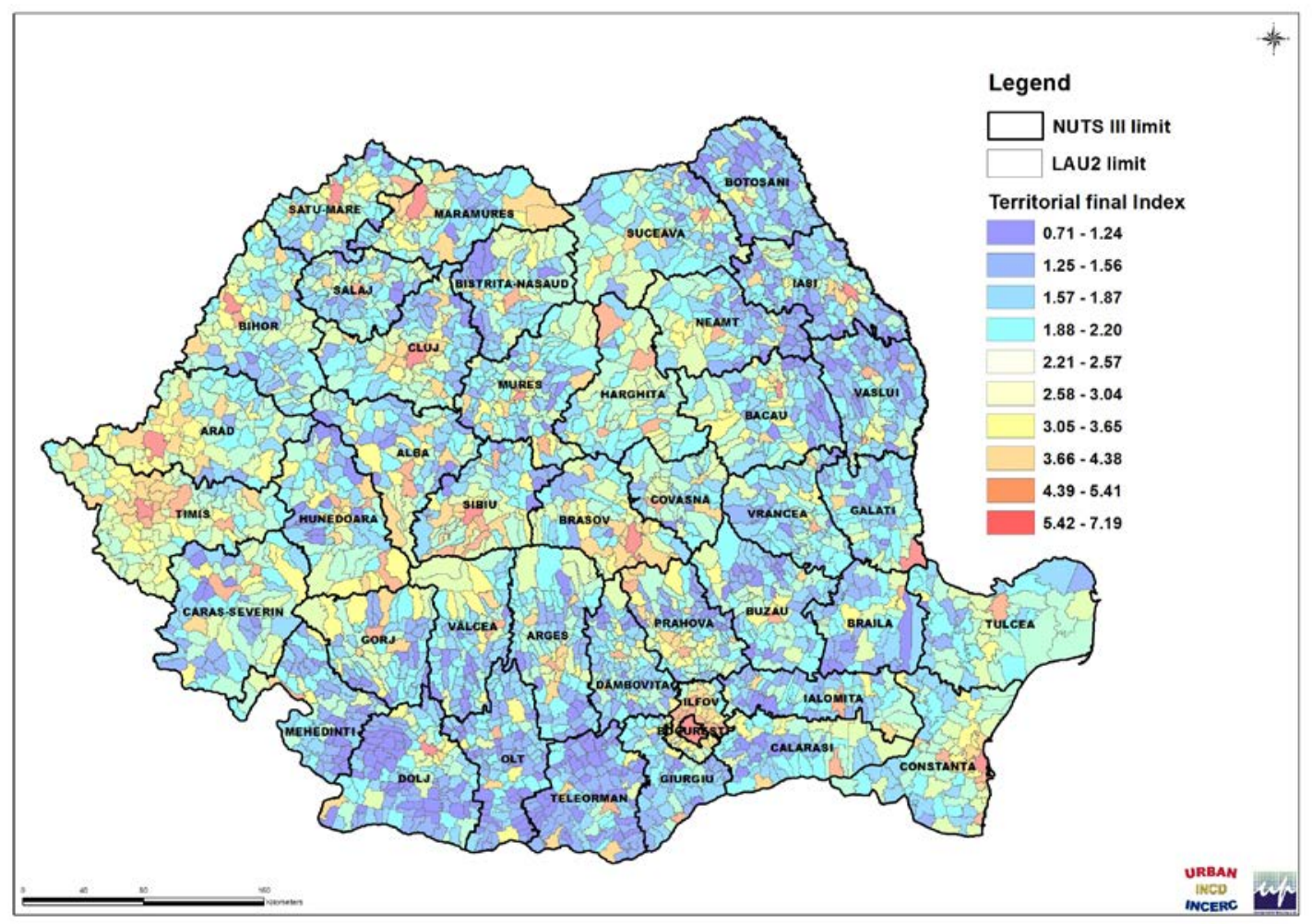

Figure 5: Final territorial index for all Romanian settlements (LAU 2) Source: Romanian National Institute of Statistics

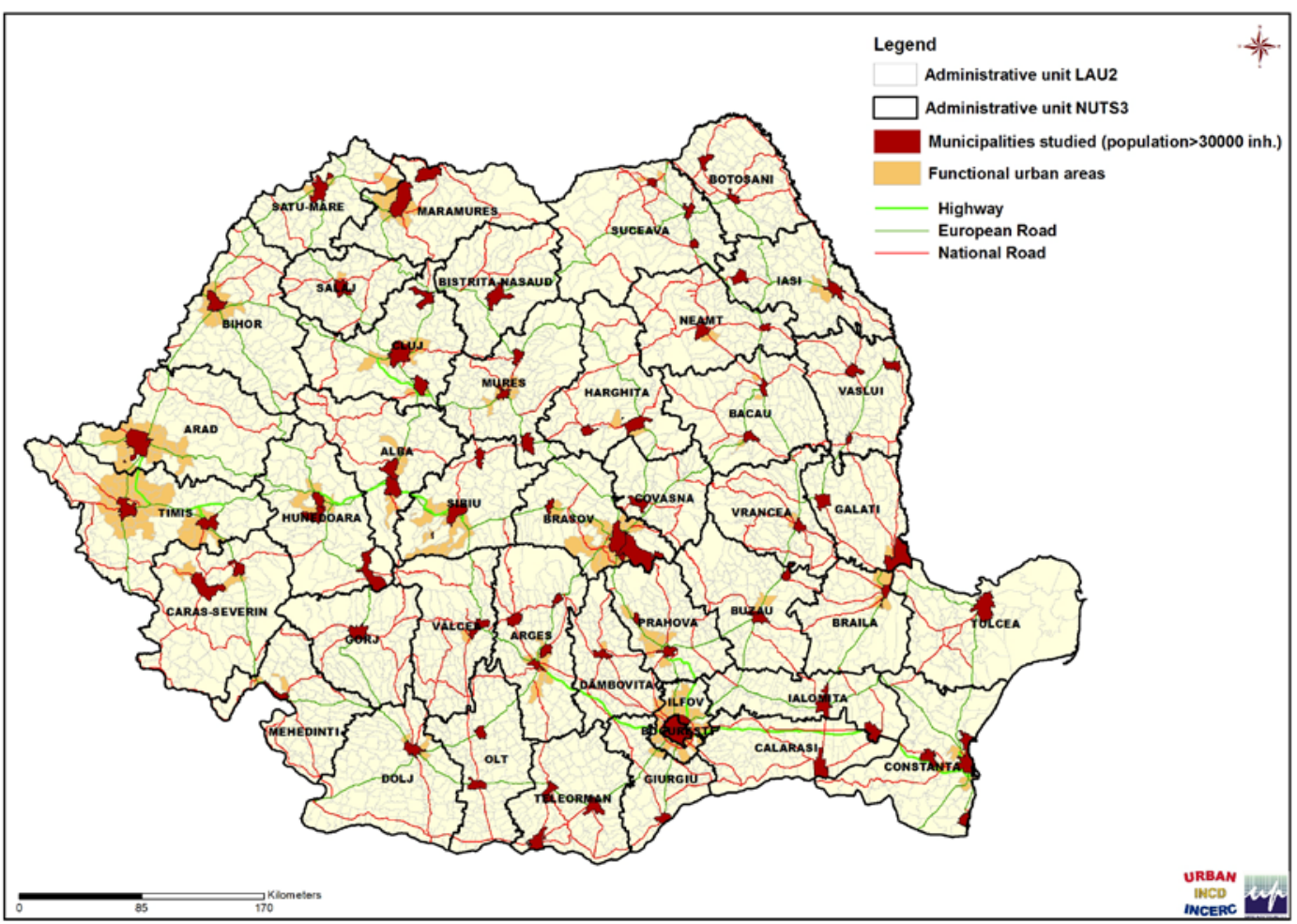

Figure 6: Assessment of functional urban areas on the basis of the described analyses Source: Romanian National Institute of Statistics - Tempo Online Database 
Limitations of the study. It has to be stressed out that the aim of the study was merely to create a methodology for assessing the Functional Urban Areas in Romania using GIS and LAU 2 territorial indicators rather than offering a current synopsis of the Romanian Functional Urban Areas. The study is the result of a funded research; the selection of data and indicators was financially constrained by the financial reasons and thus the results might not offer an accurate and detailed picture, although they are (at large) in line with the previous findings. Moreover, the analysis was oriented towards the dynamic, and particular years were chosen to reflect key historical settings described in the methodology.

\section{CONCLUSIONS}

The methodology proposed by this study is an exercise useful for evaluating the cities of Romania and neighbouring countries. The new global economic approach leads to a dynamic of urban socioeconomic development requiring a permanent monitoring for adjusting the development strategies, especially around large cities. Each city can become an attractive centre for investors and population through integrated development strategies and expansion of its functional specializations. Its positive dynamic often results into an increase of population and number of employees in the central core and its periphery.

Polycentric development can ensure effective territorial integration and can help to increase local cohesion and competitiveness through an integrated development, which takes into account the local particularities. The issue is of obvious interest, as the Europe 2020 Strategy on Spatial Planning introduces the concept of smart, sustainable, and inclusive city.

In this respect, it is necessary to implement integrated development strategies for the large Romanian cities, by adopting a comprehensive vision of the city, with a territorial development perspective that promotes, in a harmonious and integrated way, all the dimensions of urban sustainability, as well as all types of city areas, including the metropolitan ones.

In order for the metropolitan areas to achieve the objectives of economic development, sustainable development strategies and visions are necessary. Generally, the integrated approach for the development of metropolitan areas must consider those responsibilities considered crucial to the development of the metropolises and their direct surroundings, namely the public transport system, territorial marketing, and spatial planning.

The current local or county governance system does not allow for an efficient functioning of structures such as the Urban Functional Areas or the development of public-private partnerships, and a decentralization model can be useful in finding solutions for integrated territorial cooperation.

\section{ACKNOWLEDGEMENT}

This work was supported by a grant of the Romanian National Authority for Scientific Research and Innovation CNCS/CCCDI - UEFISCDI, project number PN-III-P2-2.1-PED-2016-0733 PNCDI III. 
BAUMONT, C., ERTUR, C., \& GALLO, J. (2004). Spatial Analysis of Employment and Population Density: The Case of the Agglomeration of Dijon 1999. Geographical Analysis, 36(2), 146-176.

BOIX, R., VENERI, P., \& ALMENAR, V. (2012). Polycentric Metropolitan Areas in Europe: Towards a Unified Proposal of Delimitation. In E. Fernández Vázquez \& F. Rubiera Morollón (eds.), Defining the Spatial Scale in Modern Regional Analysis (pp. 45-70). Berlin: Springer.

BREZZI, M., \& VENERI, P. (2015). Assessing Polycentric Urban Systems in the OECD: Country, Regional and Metropolitan Perspectives. European Planning Studies, 23(6), 1128-1145.

CASTELLS, M. (1996). The Information Age: Economy, Society and Culture. Volume I - The Rise of the Network Society. Malden: Blackwell Publishers.

COWELL, M. (2010). Polycentric Regions: Comparing Complementarity and Institutional Governance in the San Francisco Bay Area, the Randstad and Emilia-Romagna. Urban Studies, 47(5), 945-965.

CSD-COMMITTEE ON SPATIAL DEVELOPMENT (1999). European Spatial Development Perspective. Towards Balanced and Sustainable Development of the Territory of the EU. Postdam: Informal Meeting of Ministers Responsible for Spatial Planning of the Member States of the European Union.

DAVOUDI, S. (2003). European Briefing: Polycentricity in European Spatial Planning: From an Analytical Tool to a Normative Agenda. European Planning Studies, 11(8), 979-999.

ESKELINEN, H., \& FRITSCH, M. (2009). Polycentricity in the North-eastern Periphery of the EU Territory. European Planning Studies, 17(4), 605-619.

FALUDI, A. (2006). From European Spatial Development to Territorial Cohesion Policy. Regional Studies, 40(6), 667-678.

GIFFINGER, R., \& GUDRUN, H. (2010). Smart Cities Ranking: An Effective Instrument for the Positioning of the Cities? ACE: Architecture, City and Environment, 4(12), 7-26.

GORDON, P., \& RICHARDSON, H.W. (1996). Beyond Polycentricity: The Dispersed Metropolis, Los Angeles, 19701990. Journal of American Planning Association, 62(3), 289-295.

GUILLAIN, R., GALLO, J.L., \& BOITEUX-ORAIN, C. (2004). The Evolution of the Spatial and Sectoral Patterns in Ile-DeFrance over 1978-1997. In 50 $0^{\text {th }}$ North American Meetings of the Regional Science Association International (RSAI). Philadelphia: Science Association International.

HAGUE, C., \& KIRK, K. (2003). Polycentricity Scoping Study. London: Office of the Deputy Prime Minister.

HOYLER, M., FREYTAG T., \& MAGER C. (2008). Connecting Rhine-Main: The Production of Multi-Scalar Polycentricities through Knowledge-Intensive Business Services. Regional Studies, 42(8), 1095-1111.

JAŁOWIECKI, B. (2006). Polish Cities and Metropolisation Processes. Studia Regionalne i Lokalne, Special Issue, 75-84.

KRÄTKE, S. (2007). Metropolisation of the European Economic Territory as a Consequence of Increasing Specialisation of Urban Agglomerations in the Knowledge Economy. European Planning Studies, 15(1), 1-27.

MARULL, J., PINO, J., MALLARACH, J.M., \& CORDOBILLA, M.J. (2007). A Land Suitability Index for Strategic Environmental Assessment in Metropolitan Areas. Landscape and Urban Planning, 81(3), 200-212.

MCDONALD, J.F., \& PRATHER, P. (1991). A Polycentric Employment Density Model for the Chicago Urbanized Area. Chicago: University of Illinois.

MCMILLEN, D.P., \& MCDONALD, J.F. (1998). Suburban Subcenters and Employment Density in Metropolitan Chicago. Journal of Urban Economics, 43(2), 157-180.

MCMILLEN, D.P., \& SMITH, S. (2003). The Number of Subcenters in Large Urban Areas. Journal of Urban Economics, 53(3), 321-338.

MEIJERS, E., \& SANDBERG, K. (2008). Reducing Regional Disparities by Means of Polycentric Development: Panacea or Placebo? Science Regionali: The Italian Journal of Regional Science, 7(2), 71-96.

MEIJERS, E.J. (2008). Measuring Polycentricity and its Promises. European Planning Studies, 16(9), 1313-1323.

MEIJERS, E.J. (2008). Summing Small Cities Does Not Make a Large City: Polycentric Urban Regions and the Provision of Cultural, Leisure and Sport Amenities. Urban Studies, 45(11): 2323-2342.

MEIJERS, E.J., WATERHOUT, B., \& ZONNEVELD, W.A.M. (2007). Closing the Gap: Territorial Cohesion through Polycentric Development. European Journal of Spatial Development, 24, 1-25. 
NORDREGIO, Danish Centre for Forest, Landscape and Planning, OTB, CNRS-UMR, Centre for Urban Development and Environmental Management CUDEM, Austrian Institute for Regional Studies and Spatial Planning, Spiekermann \& Wegener, Dipartimento Interateneo Territorio, Politecnico e Università di Torino, Quarternaire, Department of Urban and Regional Planning, Norwegian Institute for Urban and Regional Research, Institute for Territorial Development and Landscape, Swiss Federal Institute of Technology, Hungarian Institute for Regional and Urban Development and Planning, \& Urban Planning Institute of the Republic of Slovenia (2005). Potentials for Polycentric Development in Europe. Final Report 1.1.1. Stockholm: Nordregio.

PETRIŞOR, A.-I. (2016). Geographical Information Systems as Environmental, Landscape and Urban Planning and Research Tools. Romania as a Case Study. In M. Bostenaru-Dan \& C. Crăciun (eds.), Space and Time Visualization (pp. 233-249). Geneva: Springer Nature.

PETRIŞOR, A.-I. (2017). A Diversity-based Approach to the Spatial Development of Socio-Ecological Systems. Urbanism Architecture Constructions, 8(2), 143-162.

PRIVELLI, M. (2003). Funkja metropolitalna a proces globalizacji. Studia Regionalnei Lokalne, 14(4), 65-75.

SASSEN, S. (2001). The Global City: New York, London, Tokyo. Princeton: Princeton University Press.

SCHINDEGGER, F. (2002). Herausforderungen und Strategien für eine Raumentwicklungspolitik in Österreich. Salzburger Institut für Raumordnung \& Wohnen (Hrsg.). SIR-Mitteilungen und Berichte, 30, 99-104.

TACHE, A.V., \& PETRIŞOR, A.-I. (2017). GIS-based IT Model for Assessing Territorial Accessibility in Romania. International Journal of Human Settlements, 1(2), 13-23.

TACHE, A.V., \& TACHE, M. (2016). A Methodology for the Evaluation of Functional Urban Areas in Romania. Romanian Journal of Geography, 60(1), 73-83.

TACHE, A.V., MANOLE, S.D., \& PETRIŞOR, A.-I. (2018). Metropolization of Large Urban Centers in Romania: Analyses and Solutions. Algerian Journal of Engineering Architecture and Urbanism, 2(1), 8-17.

TACHE, A.V., MANOLE, S.D., TACHE, M., \& PETRIŞOR, A.-I. (2016). Analysis of the Polycentricity of Romanian County Residences. Urbanism Architecture Constructions, 7(4), 301-320.

TACHE, A.V., POPESCU, O.C., \& TACHE, M. (2017). GIS Mathematic Model Analyzing the Attractiveness of the Romanian Settlements Network, Assessing the Competitiveness Factors at National Level. Romanian Statistical Review, 65(S9), 83-102.

TRULLÉN, J., \& BOIX, R. (2001). Economia della conoscenza e reti di città: Città creative nell'era della conoscenza. Sviluppo Locale, 8(18), 41-60.

TRULLÉN, J., \& BOIX, R. (2003). Barcelona, Polycentric Metropolis and Network of Cities. In Workshop on Spatial Networks and Clusters: Urban and Regional Prosperity in a Globalised Economy. Tarragona: Universita Rovira I Virgili.

VAN DER LAAN, L. (1998). Changing Urban Systems, an Empirical Analysis at Two Spatial Levels. Regional Studies, 32(3), 235-247. 